\title{
中性子反射率計
}

武田 全康, 山㠃 大，日野 正裕*

(日本原子力研究開発機構 原子力科学研究部門, 京都大学 原子炉実験所 ${ }^{*}$ )

\section{Neutron Reflectometer}

Masayasu Takeda, Dai Yamazaki and Masahiro Hino*

Sector of Nuclear Science Research, JAEA and Kyoto University Research Reactor Institute*

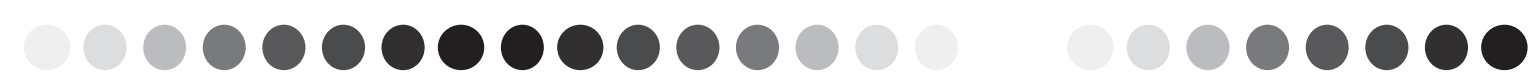

\begin{abstract}
The neutron reflectometer is the most powerful and nondestructive tool to analyze the surface and buried interfaces in the layered films. Such films often have a close relation to the functional devices. Structural information in the vicinity of the interfaces is a key parameter in the field of the nanoscale science.

Keywords: surface, interface, structure, neutron reflectometry
\end{abstract}

1. 何が分かるか

波長の長い中性子に顕著であるが，中性子を物 質表面に対して，非常に浅い角度で入射させると (この場合，Fig.1に示すように，法線方向から測 られる入射角は $90^{\circ}$ に近い)，中性子は，鏡面反 射，屈折，透過という我々が日常生活で眼にする 可視光の光学的性質を示し，これを中性子光学現 象と呼ぶ. 中性子反射率計は，この中性子光学現 象を利用して, 表面の状態や, 層状構造を持つ物 質内部の構造を非破壊的に調べることのできる装 置である. 本稿では入射角と反射角が等しい鏡面 反射を基本的に扱うが，鏡面反射は，その名が示 すように，鏡面，すなわち，平坦な表面や界面を もつ層状構造物質に対して起こり, それら表面や 界面に対して深さ方向の構造情報が得られる.

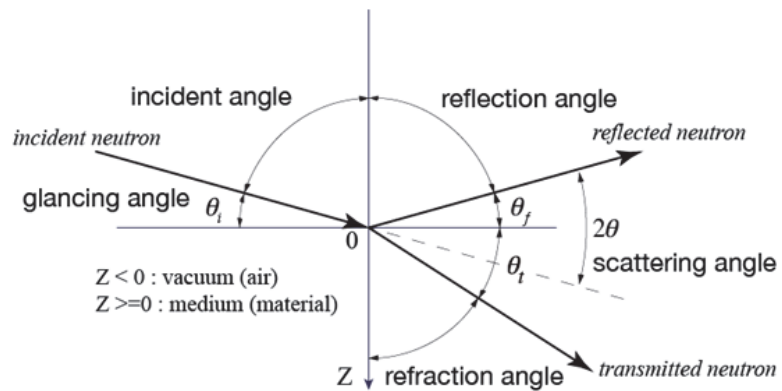

Fig. 1 The definition of angles in the scattering plane.

実際の物質では, 表面や界面の粗さ (ラフネス) の存在により, 多かれ少なかれ非鏡面反射が起こ つている。また，面内が一様でなく構造を持つ場 合にも，非鏡面反射が起こる。一般的に，非鏡面 反射には面内構造が反映されている。「波紋」には， 「中性子反射率入門講座」が過去に掲載されてお
り [1]，そちらもお読みいただけると，非鏡面反射 率を含む応用例に触れることができる.

\section{2. 基本原理 $[2,3]$}

2.1. 屈折率とスネルの法則

「中性子反射率法の原理」は上述の入門講座や 他にも説明があるので $[2,3]$ ，ここでは，以下を 読み進める上で必要になる最低限の原理のみを説 明し，詳細を省く．中性子光学現象による中性子 の物質に対する振る舞いを決めるのは，下記のス ネルの法則で,

$$
n(q)=\frac{\cos \theta_{i}}{\cos \theta_{f}}=\frac{\lambda_{i}}{\lambda_{f}}=\frac{v_{f}}{v_{i}}=\sqrt{1-\frac{4 \pi \rho b}{q^{2}}}
$$

そこに登場する物質固有の量は次元を持たない屈 折率 $n$ である。中性子は物質波なので，波長 $\lambda$ と 速さ $v$ が反比例することに注意する。式(1)に現れ る $\rho$ は媒質を構成する物質の密度, $b$ は物質の核 散乱長， $q$ は散乱ベクトルの大きさである. $q$ の 方向は試料表面（反射面）に垂直で，弾性散乱と 同じように， $q=4 \pi \sin (2 \theta / 2) / \lambda$ で定義される. 屈折率は一様媒質に対して定義されるから, 結晶 構造などのミクロな構造は直接反射率には反映さ れない。「直接」と書いたのは，含まれる元素や密 度には影響を受けるからである。従って，物質が 複数の元素からできている場合には，式(1)の $b$ は 結晶の場合，ユニットセル内の全ての構成元素の 核散乱長の総和となる。式(1)からは屈折率には $q$ 依存性があることがわかる. 定常炉では TOF 法が 使われることもあるが，一般的な角度分散型の測 定では, 波長は一定と見なすから, 視斜角 (Fig. 1) に応じて屈折率が変わる。 
試料を構成する物質が磁性体である場合には， 屈折率は，中性子スピンの状態 $( \pm \hbar / 2)$ にも依存 するが, 入射中性子のスピンがそろっていない(両 方のスピン状態が同数含まれる）非偏極中性子で は，平均化されてしまいその違いを見分けること ができない。しかし，どちらかのスピン状態しか 持たない偏極中性子を使うと, 屈折率に中性子の スピン依存性が下記のように現れる。

$$
n(q)=\sqrt{1-\frac{4 \pi \rho(b \pm p)}{q^{2}}}
$$

ここで, $p$ は磁気散乱長と呼ばれ磁気モーメント に比例する量で, 1 Bohr 磁子が 0.27 fm に対応す る. $p$ の前の複号は試料位置の外部磁場によって 決まる量子化軸に対して中性子スピンが平行な場 合に+, 反平行な場合に-を取る. 複数の磁性元素 を試料が含む場合には，核散乱長と同じように， 結晶の場合，ユニットセル内で足し合わせる。

鏡面反射に関する基本原理はたったこれだけで ある，反射率計は，測定対象を構成する物質で決 まる屈折率を測定する装置だから，それ以上のも のではなく，あまり知られていない装置ではある が，非常に単純なのである。以下，試料の厚さが 無限大と見なせる場合と, そうでない場合につい て具体的によ゙のような情報が得られるかを見てみ よう.

\section{2. 試料の厚みが無限大と見なせる場合}

試料の厚みが十分に厚く，大気（以後真空と等 価に扱い，両者を区別しない）から試料に入射し た中性子が，最初の界面である表面には到達する が，その下の物質界面（単一の物質である場合に は試料の裏側）に達しない場合である。この場合 は, Fig. 2 (a)に示すように, 次の界面に到達する 前に, 中性子は試料の脇から抜けてしまうため,

2.3 でみる有限の厚さの膜からの反射のように干 涉効果が見られない。この場合単純に試料表面で のみ反射が起こり， $q$ の小さなところでは，全反 射がおきるものの, Fig. 3 の Ni 表面に対するシミ ユレーション（Ni infinite）が示すように，qが大 きくなるに従って反射率は急速に減衰する.

( a )

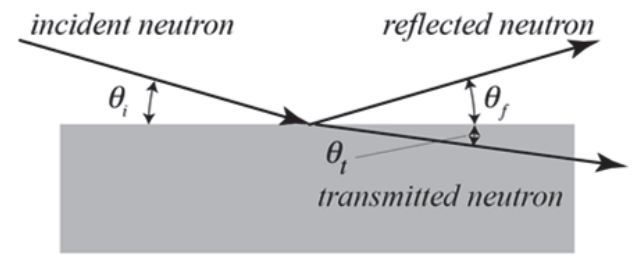

(b)

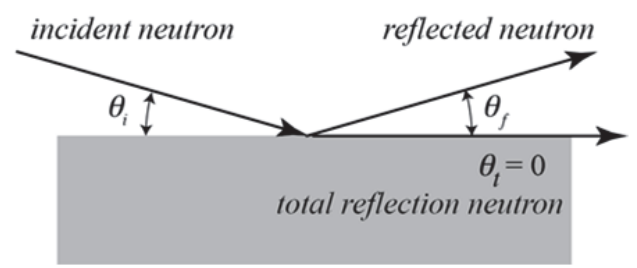

Fig. 2 (a) Reflection and refraction on the surface of the sample with an infinite thickness, and (b) the total reflection.
全反射が起きる条件は，屈折率が虚数になること なので，式(1)から，全反射が起こるか起こらない かの境界の $q$ を $q_{c}$ とすると, 非磁性試料の場合に は, $q_{c}=\sqrt{4 \pi \rho b}$ となり, 散乱長密度を知ること ができる。

また，理想的な表面からの反射率 $R_{0}$ が，表面ラ フネスの存在によって下記の様に減衰することが 知られており, 減衰因子は, static Debye-Waller 因 子と呼ばれる。

$$
R=R_{0} \exp \left(-\sigma^{2} q^{2}\right)
$$

$\sigma^{2}$ は反射面全体の理想平滑界面からの高さ方向 のずれの 2 乗平均である. この減衰の $q$ 依存性か ら，表面ラフネスの值を定量的に得ることができ る.

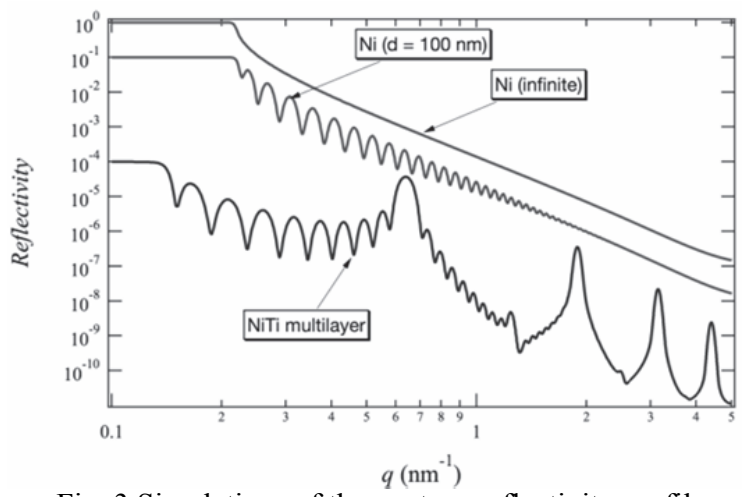

Fig. 3 Simulations of the neutron reflectivity profile.

\section{3. 試料厚みが有限な場合}

表面で屈折した中性子が，次の界面に達して， その界面でも反射と屈折が起こると，表面とそれ らの界面で反射した中性子との位相の違いによっ て干渉が起こる. 中性子光学では, 中性子を平面 波として扱うので, 現象としては光学的干渉縞と 基本的には同じ現象である（可視光との違いは， 界面が自由端となるか固定端となるかである。自 由端の場合には反射の際に, 位相が $\pi$ 変わる). 複 数の界面が, 試料の内部に存在するときの, 反射 率プロファイルシミュレーション例を Fig. 3 に, 反射・屈折の様子を Fig. 4 に示した. Fig. 3 では反 射率曲線の違いを見やすくするために，後にみる 多層膜の例も含めて, 縦軸をずらしてある.低い $q$ 領域に観られる $q$ の変化に対して平坦な領域であ る全反射の值はすべて 1 である.

同じ $\mathrm{Ni}$ であっても試料の厚さが薄くなると, 表 面で反射した中性子と，基板界面からの反射波と 干渉を起こすため, $q$ に対する単純な強度の周期 的な変動である干渉縞が現れる。この例では，ガ ラス基板の上に $100 \mathrm{~nm}$ の $\mathrm{Ni}$ が蒸着されていると 仮定した。干渉縞の間隔は, この $100 \mathrm{~nm}$ と屈折 率により決まるため，反射率測定から，基板上の 単層膜の厚さを決めることができる，正確には， 干渉縞の間隔 $\Delta q$ は， $2 \pi / n D \mathrm{~nm}^{-1}$ と表される. $n$ と $D$ はそれぞれ，単層膜の屈折率と厚さである. したがって，あまり厚くなると，干渉縞の間隔が 
狭くなって，干渉縞が見えなくなる．どの程度の 厚さまで見えるかは装置分解能との兼祮合いで決 まるが，JRR-3 に設置されている反射率計では， $1 \mu \mathrm{m}$ 程度が限界である.

一方，どこまで薄いところまで測定できるかは 屈折率と厚さによって変わる. 反射率計は, 単層 膜の場合には，空気と膜と基板の屈折率の差（コ ントラスト）を，多層膜では，各界面をはさむ層 間のコントラストを観ることになる。 そのため, 膜が厚くても屈折率に差が無ければ，そこに界面 があると中性子は認識しないし，薄くても大きな コントラストがあれば，その薄い層の存在を感じ 取って, 中性子反射率曲線に変化が現れる. 山崎 らは, SUIRENを用いて, 水素終端した $\mathrm{Si}$ 基板上 に成膜した $\mathrm{Sr}$ と基板との間に残存する 1 原子層の 水素を見分けることに成功している [4].

単層ではなく, 試料内部に多層構造がある場合 も，反射率プロファイルは複雑になるが，試料内 の屈折率 (核散乱長密度を介した物質とその密度) と深さ方向の構造変化の情報が導き出せる. Fig. 3 に示した例は, $\mathrm{Si}$ 基板の上にそれぞれ，5 $\mathrm{nm}$ の厚 さを持つ $\mathrm{Ni} / \mathrm{Ti}$ の一対の層（bilayer）を 10 回積層 したものである。この場合には， $5+5=10 \mathrm{~nm}$ の 構造が 10 回繰り返されていることによる Bragg 反射的ピークが高次まで見えている．

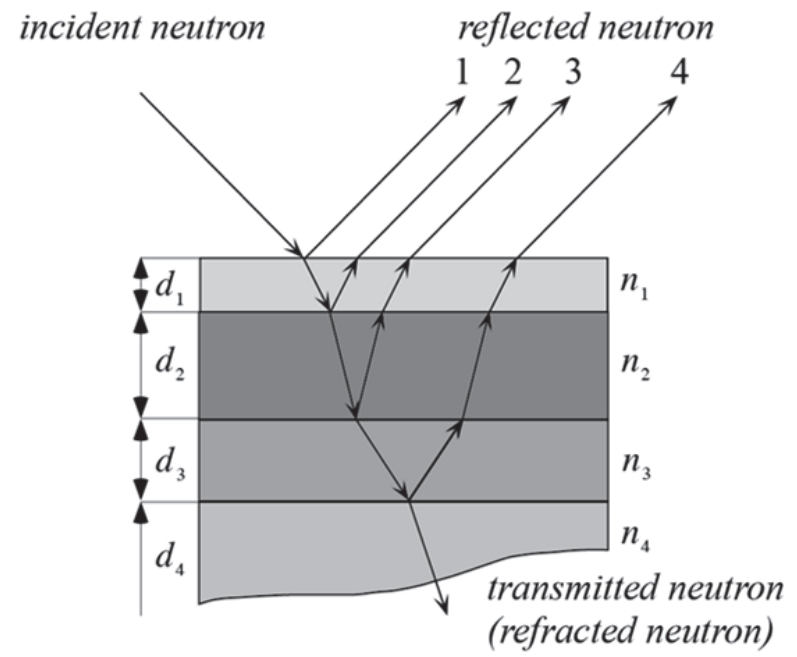

Fig. 4 Successive reflection and refraction at each interface.

\section{3. 典型的な実験条件}

研究用原子炉 JRR-3 には SUIREN と MINE2 の 2 台の反射率計が設置されているが，ぞちらも試料 面（反射面）を鉛直面に置き，散乱面を水平面内 に置く試料垂直型の角度分散型中性子反射率計で ある。すでに説明したように，角度分散型では， 特定の波長の中性子を利用して, 視斜角之散乱角 を変化させながら反射率の測定を行うが, 視斜角 と散乱角を文字通り 1:2 の関係を保ちつつ動か寸 $\theta-2 \theta$ スキャンを行う. Table 1, 2 に 2 台の反射 率計の諸元をまとめる.

測定可能な反射率という観点で見れば，研究室
の X 線反射率計とほぼ同レベルである。また試料 垂直型の反射率計では，試料が自立できなくては ならないので, 気体/液体のような自由界面の測定 はできない（これにはJ-PARC SOFIA (BL16)の様 な試料水平型の反射率計が必要）が，容易に電磁 石などの大型試料環境と組み合わせられること， 大きな $q$ 領域まで測定できることが特徵である.

SUIREN と MINE2 の詳細は文献 [5] に詳しいの で，ここでは，主に典型的な実験条件を述べる。

反射率は深さ方向に $1 \mathrm{~nm}$ 以下の分解能で非破 壊測定が可能だが，そのためには，同程度のラフ ネスを持つ平滑な基板が必要であることに加え, 平面度も重要である. そのため, 数 $\mathrm{mm}$ 以上の比 較的厚めの基板上に成膜した試料がよく使われる. 薄いガラス基板や $\mathrm{Si}$ 基板に片面蒸着した試料で は，試料に反りが生じていることが多く，このよ うな試料は測定に適さないので工夫が必要である.

Table 1 Specifications of the SUIREN reflectometer.

\begin{tabular}{|l|l|}
\hline Wavelength $(\mathrm{nm})$ & 0.393 \\
\hline Wavelength resolution $(\%)$ & 2.6 \\
\hline Intensity $\left(\mathrm{n} / \mathrm{cm}^{2} / \mathrm{s}\right)$ & $\left.\begin{array}{l}\sim 1.6 \times 10^{4} \\
\left(\delta \theta=0.08^{\circ}\right.\end{array}\right)$ \\
\hline Maximum beam size $\left(\mathrm{mm}^{2}\right)$ & $60(\mathrm{H}) \times 10(\mathrm{~W})$ \\
\hline$q$ range $\left(\mathrm{nm}^{-1}\right)$ & $<4.0$ \\
\hline Reflectivity & $>10^{-6}$ \\
\hline Detector property & $\begin{array}{l}{ }^{3} \mathrm{He} \text { point detector \& } \\
\text { one-dimensional } \\
\text { position sensitive } \\
\text { detector }(1 \mathrm{~mm} \\
\text { spatial resolution. })\end{array}$ \\
\hline
\end{tabular}

Table 2 Specifications of the MINE2 reflectometer.

\begin{tabular}{|l|l|}
\hline Wavelength $(\mathrm{nm})$ & 0.88 \\
\hline Wavelength resolution $(\%)$ & 2.7 \\
\hline Intensity $\left(\mathrm{n} / \mathrm{cm}^{2} / \mathrm{s}\right)$ & $\sim 1.5 \times 10^{4}$ \\
\hline Maximum beam size $\left(\mathrm{mm}^{2}\right)$ & $50(\mathrm{H}) \times 3(\mathrm{~W})$ \\
\hline$q$ range $\left(\mathrm{nm}^{-1}\right)$ & $<10.0$ \\
\hline Reflectivity & $>2 \times 10^{-6}$ \\
\hline Detector property & ${ }^{3} \mathrm{He}$ point detector \\
\hline
\end{tabular}

MINE2 では，中性子光学素子など，反射率が特 別大きいものは別として，基板サイズとしては， 直径 3 インチや $50 \mathrm{~mm}$ 角と比較的大きなものが 望ましい. SUIREN では, 縦 $60 \mathrm{~mm}$, 幅 $10 \mathrm{~mm}$ の大きさの入射中性子が使えるから, 最大で縦 60 $\mathrm{mm}$, はば $10 / \sin \theta \mathrm{mm}(\theta$ : 視斜角 $)$ までの試料 サイズが可能であり，やはり試料サイズが大きい 方が，反射中性子強度がより強くなり，測定時間 が短縮されたり，より小さな反射率を測定するこ とができるので有利である.しかし，その一方で， 試料サイズが大きいと, 試料面内の均一性が問題 になる場合やビームの発散角が増加することによ り，かえって $\mathrm{S} / \mathrm{N}$ が悪くなることもあり，単純に 
試料サイズが大きければ良いというわけではない. 各反射率計の特性とその反射率測定によってどの ような情報が重要なのか考えながら, 試料サイズ を選択する必要がある。

SUIREN では, 電磁石や $10 \mathrm{~K}$ 冷凍機と組み合わ せる場合, 試料の大きさに制限がでてくる. 室温 で $10 \mathrm{kOe}$ までの測定を行う場合には, 試料の縦 (鉛直) 方向が， $50 \mathrm{~mm}$ 未満であること, 冷凍機 とともに使う場合には, 直径 $20 \mathrm{~mm}$ 未満である ことが必要となる。

測定可能な反射率の下限だけ見れば，研究室の $\mathrm{X}$ 線反射率計とほぼ同レベルである。物性測定に おいて, X 線反射率法と比較した場合の, 中性子 反射率法のメリットは，大きくは，下記 5 点であ ろう。

(1) 中性子は強い透過性を持つため，基板側から でも中性子を入射でき, 固体/液体を直接観察 できる

(2) $\mathrm{H}, \mathrm{Li}, \mathrm{C}, \mathrm{B}$ などの軽元素にも十分な感度があ る

(3) 周期律表で隣り合う元素の区別ができる

(4) 化学的にほとんど同じだが中性子では散乱長 の異なる同位体（特に軽水素と重水素）でコ ントラストをつけることが出来る

(5) 偏極中性子を用いることで磁気構造の情報が 得られる

(2)から (5)に関しては，反射率法に限らず，中性 子散乱実験一般に関して言えることである。ここ では, 反射率測定に特有な, 基板から中性子ビー ムを入射させる場合に注目してみたい，基板入射 の場合には， $10 \mathrm{~mm}$ 程度の厚さの基板を用いるこ とが多い。 また, 良く使われるのは, シリコン基 板や石英ガラスである。これは平滑及び平面度だ けでなく, 透過性が良くかつ小角散乱をほとんど 起こさないことも必要となるためである.

このように基板の材質はシリコンや石英に固定 されてしまうが，測定したい界面を強調するため や, 試料作製 (例えばポリマーブラシ等をはやす) のために，基板に必要な膜を挿入することが有効 な場合もある。このためにも実験前に層構造のモ デルをたてて反射率を予想し, 実験の可能性を検 討することが必須であり，これは測定データの処 理（フィッティング）ソフトで比較的容易に行え る. フィッティングソフトは, フリーでダウンロ ード可能である [6].

\section{4. 実験例の紹介}

中性子反射率測定の実験例は，すでに文献[1]や [7]にあるので, ここでは, まず最近日本から研究 が始まった摩擦, 特に潤滑現象の解明に向けた中 性子反射率法によるアプローチの実験例を紹介し たい $[8,9]$. トライボロジーの分野で, 潤滑油に適 切な添加物を足すことで, 摩擦係数が小さくなる ことが良く知られているが，その構造は定かでは
ない，しかし潤滑現象は系が平均化されているこ とが多く, 固体最表面近傍での潤滑剤の平均構造, 密度，挙動に中性子反射率法は力を発揮する.

Fig. 5 に固体/液体界面測定用サンプルホルダー の概略図を示寸. 基板には $50 \mathrm{~mm}$ 角(厚さ $10 \mathrm{~mm}$ ) のシリコン基板を用い，その表面に銅や鉄を 70 $\mathrm{nm}$ 程度蒸着している. 鉄や銅は一般の材料を模 擬するとともに，添加剤を入れたことによる吸着 層をより見やすくするためである. なお $70 \mathrm{~nm}$ と いう厚みは事前に中性子反射率シミュレーション ソフトウエアを用いて最適化した。

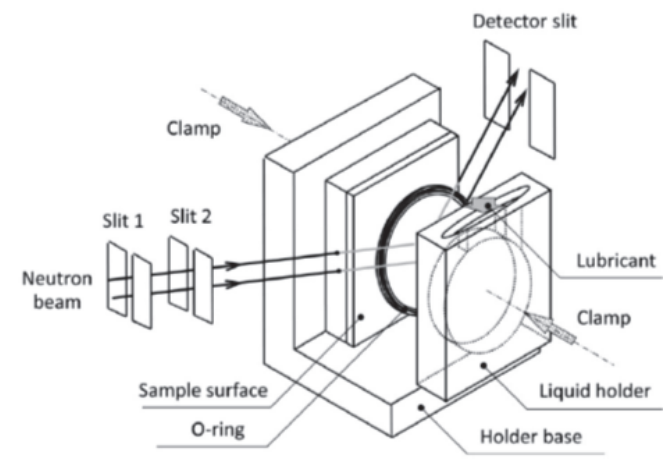

Fig. 5 Schematic view of a sample holder to measure solid/liquid interface by using neutron reflectometry [9].

Fig. 6 にこのサンプルホルダーを用いて，銅を ベースとした固体/液体界面の中性子反射率の結 果を示す。まず, 空気中（In air）での銅薄膜の測 定を行った。これにより銅の厚さは $74 \mathrm{~nm}$, 散乱 長密度は $6.0 \times 10^{-4} \mathrm{~nm}^{-2}$ と評価できた。次ぎに潤滑 油の一般的なべースオイルである PAO（ポリアル ファオレフィン) 中に銅薄膜を入れて, シリコン 基板側から中性子を入射して反射率測定を行った. この時の中性子の透過率は入射側と出射側を含め て約 $80 \%$ である. 空気中の測定と比較して, 干渉 縞の周期（つまり膜厚）が変化していないことが 分かる。ここでは，干渉縞の周期が見えやすいよ うに， のマークを入れている.

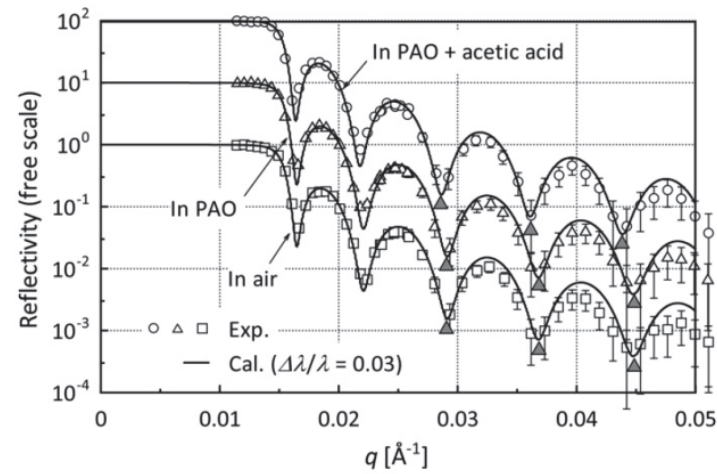

Fig. 6 Reflectivity of neutron by copper surface in air, PAO (Poly-Alpha-Olefin), PAO and acetic acid.

ここに添加剤として重水素化した䣷酸を質量濃 度で $0.1 \%$ \%だ加えると，干渉縞の周期が短くず れた。これらの反射率データを解析して, 層構造 をモデル化した図を Fig. 7 に示す. 重水素化酢酸 
を添加することで，新たに銅の表面に散乱長密度 で $5.0 \times 10^{-4} \mathrm{~nm}^{-2}$, 厚みで $2 \mathrm{~nm}$ の層が出来ている. 重水素化酢酸の $25{ }^{\circ} \mathrm{C}$ の密度は $1.119 \mathrm{~g} / \mathrm{cm}^{3}$ であり, これより散乱長密度は $5.4 \times 10^{-4} \mathrm{~nm}^{-2}$ と計算できる。 質量濃度 $0.1 \%$ だけの添加にも関わらず, ほぼバル クに近い密度で吸着していることが分かる。また 䣷酸の分子鎖の長さは $0.5 \mathrm{~nm}$ 以下なので, 多層構 造をしていると考えられる。なお，実際に潤滑油 に利用されている添加剤は酢酸とは異なるが,

$\mathrm{PAO}$ に䣷酸を添加することで摩擦係数の減少を トライボメーターで確認している。本研究例は $10^{-3}$ 程度までの反射率測定で十分であったが MINE2 やSUIRENではこれより 1 桁以上は低い反 射率まで測定可能である。

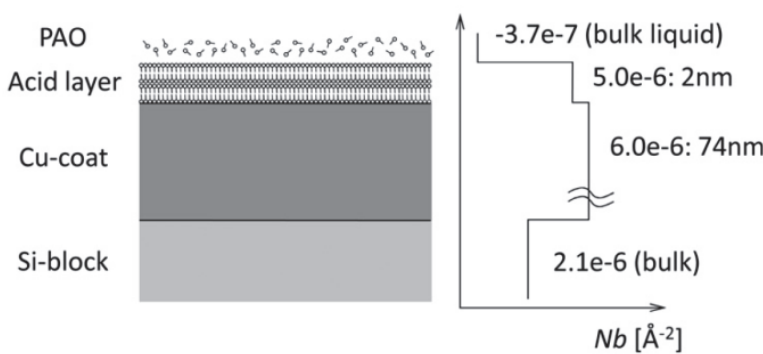

Fig.7 Layer structure estimated by fitting the reflectivity [9].

次に，SUIREN で測定した偏極中性子反射率測 定の例を紹介する。偏極中性子反射法は，特に強 磁性層を含む多層膜試料の測定に有効で, 磁化べ クトルの深さ方向分布を化学的な多層構造とは独 立して測定することが可能である（ただし，磁化 ベクトルは面内成分のみが観測可能で，面直成分 をみることはできないという選択則に注意が必要 である） [2, 3].

磁気記録媒体，磁気へッドなどのデバイスにお いて, 磁性多層膜とその磁気異方性は決定的な役 割を果たしている。ここでは MRAM の動作原理 として重要な交換バイアス現象を起こす強磁性体 /反強磁性体界面の磁気構造解析の例を紹介する [10]. この例では, MnIr/CoFe 界面の磁気構造と交 換バイアスの関連性及びそこに反強磁性 MnIr 層 への熱処理が与える効果に注目したものである.

試料は $\mathrm{Si}$ 基板上に $\mathrm{Ta}(1.0 \mathrm{~nm}), \mathrm{Ru}(2.0 \mathrm{~nm}), \mathrm{MnIr}$, $\mathrm{CoFe}, \mathrm{Ru}(2.0 \mathrm{~nm})$ の順にスパッタ成膜したもので ある. MnIr 層および CoFe 層の厚みが異なる 4 種 の試料 $\mathrm{A}, \mathrm{B}, \mathrm{C}, \mathrm{D}$ を用意した. 熱処理の効果を 見るため, MnIr 層成膜は, 試料 A, B は室温下で,

C, D は $300{ }^{\circ} \mathrm{C} の$ 条件下で行っている。また，成 膜後に磁場 $15 \mathrm{kOe}$ を面内方向に印加して field cooling を行い, 交換バイアス現象の起源と考えら れているピン止めスピンが $\mathrm{MnIr} / \mathrm{CoFe}$ 界面に出来 るようにした．測定時には磁場 $1 \mathrm{kOe}$ を面内方向 でかつ交換バイアスと垂直な方向に印加した。こ れらの結果を Fig. 8 に示す.

$R_{++}, R_{--}$はそれぞれ印加磁場方向に平行, 反平 行に偏極した中性子がスピンの向きを変えずに反 射した反射率である. 一方, $\bar{R}_{+-}=\left(R_{+-}+R_{-+}\right) / 2$ は
反射時に中性子スピンの向きが逆転したときの反 射率であり， $\bar{R}_{+-}$が 0 でないことは印加磁場と垂 直方向（つまり交換バイアス方向）の磁気モーメ ント，つまりピン止めスピンが試料膜内に残って いることを示唆している.これらの反射率データ を解析した結果, MnIr/CoFe 界面付近の磁化ベク トルは印加磁場方向に対して Fig.9 のような傾き фを持つことが分かった。

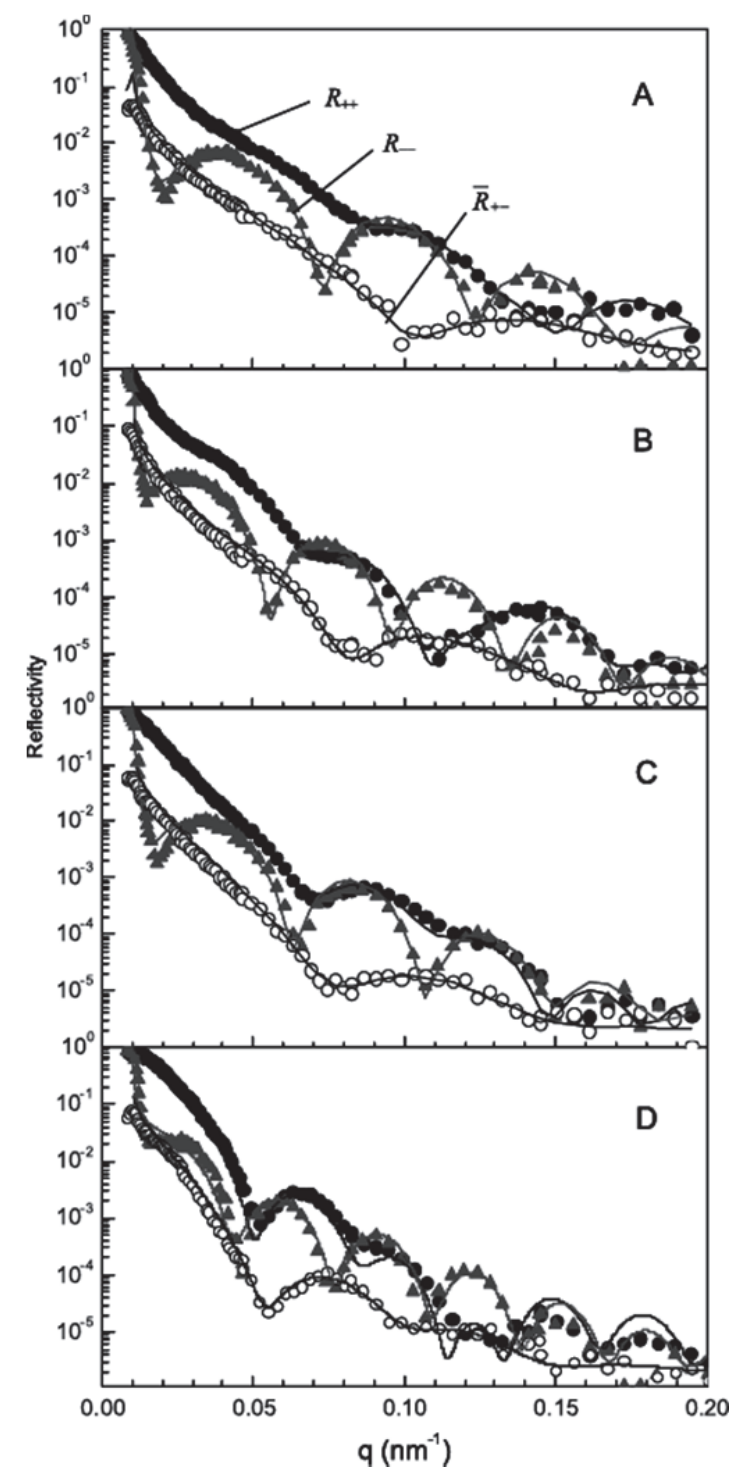

Fig. 8 Reflectivity curve for samples A-D. The closed circles represent the measured data of $R_{++}$, closed triangles represent $R$, and open circles represent $R_{+-}=\left(R_{+-}+R_{-+}\right) / 2$ [10].

すなわち，どの試料の磁化べクトルも MnIr 層 との境界 $(Z=0)$ に近付くにつれて印加磁場方向 からの傾き $\phi$ を増し, その傾きは MnIr 層の成膜時 に $300{ }^{\circ} \mathrm{C}$ 熱処理をした試料 C，Dの方で顕著で

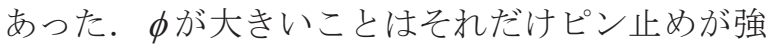
いことを示している。結果として，ピン止めされ た Mn スピンが試料 A, B では $\mathrm{MnIr} / \mathrm{CoFe}$ 界面 $1 \mathrm{~nm}$ の領域に，試料 C，Dでは同じく $3 \mathrm{~nm}$ の領域に存 在していることが分かった。すなわち, MnIr 層成 膜時に加熱処理したことによりピン止めされた 
Mn スピンの領域が広がり，それが交換バイアス 効果の増大につながっていることを示唆している.

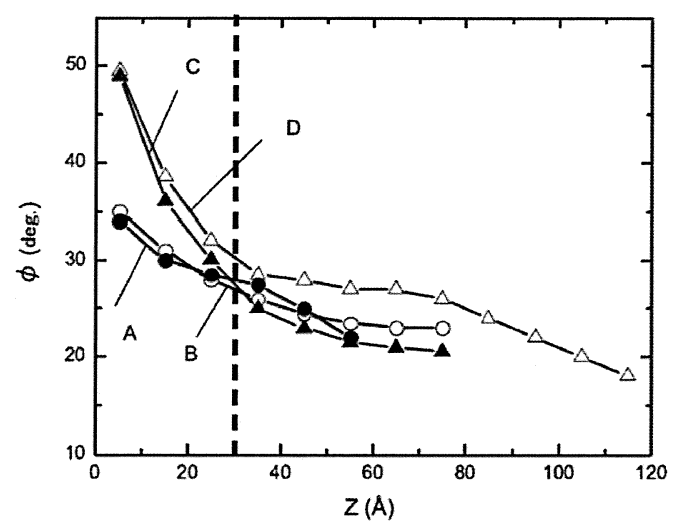

Fig.9 The depth-dependent rotation angle of the magnetization vector in samples A-D. In the figure, $\mathrm{Z}=0$ corresponds to the $\mathrm{MnIr} / \mathrm{CoFe}$ interface [10].

\section{5. 最後に}

国内外に眼を向けると, パルス中性子源, 原子 炬中性子源を問わず, 数多くの中性子反射率計が 設置されており，JRR-3 やMLF だけでなく，ひと つの中性子実験施設の中に，複数の反射率計を置 くことが主流となっている，特定のqに対する反 射率だけではなく, ある $q$ 領域での反射率の変化

（反射率プロファイル）が重要な反射率法では, TOF 法により, 有限のバンド内の波長を一度に使 えるパルス中性子源の方が圧倒的に有利であると 思われがちである。しかし，MINE2 や SUIREN な どの定常中性子源に設置された反射率計では，装 置が厚い遮蔽体に覆われていないので，試料周り が開放的でアクセスが良いことに加え，データ収 集装置（DAQ）や，装置そのものの仕組みが単純 である. そのため, 測定が直感的で, 中性子反射 率実験を最初に体験する装置としてお勧めできる. また，容易にビームライン機器配置を変更できる など，自由度に優れているので，特殊環境下での 測定や新しい測定手法の開発を行いやすいのも魅 力である. MINE2 や SUIREN の装置担当者は, 中 性子光学デバイス開発の経験や, 反射率試料の成 膜方法にも知見があるので，中性子反射率測定を お考えの方は，筆者まで，お気軽にご相談いただ ければ幸いである。

\section{参考文献}

[1] 高原淳,波紋 18, 220 (2008).

[2] 鳥飼直也,武田全康,波紋 18, 221 (2008).

[3] 武田全康, RADIOISOTOPES 59, 675 (2010).

[4] T. Yamazaki, H. Asaoka, T. Taguchi, S. Yamamoto, D. Yamazaki, R. Maruyama, M. Takeda, and S. Shamoto, Thin Solid Films 520, 3300 (2012).

[5] 山崎大，日野正裕，波紋 19, 34 (2009).

[6] 例えば, Motofit (http://motofit.sourceforge.net /wiki/index.php/Main_Page) .
[7]「中性子利用技術移転推進プログラム」業務 実施結果報告書【参考資料】中性子利用事例集 (7) 薄膜材料-1 薄膜材料-2, http://www.mext.go.jp/a_menu/ shinkou/ryoushi/detail/1323226.htm.

[8] 平山朋子, 波紋 19, 18 (2009).

[9] T. Hirayama, T. Torii, Y. Konishi, M.Maeda, T. Matsuoka, K. Inoue, M. Hino, D. Yamazaki, M. Takeda, Tribology International 54, 100 (2012).

[10] N. Awaji, T. Miyajima, S. Doi, K. Nomura, J. Phys. : Condens. Matter 22, 474012 (2010). 